\title{
Streamflow—Water Year 2019
}

\section{Introduction}

The maps and graphs in this summary describe national streamflow conditions for water year 2019 (October 1, 2018, to September 30, 2019) in the context of streamflow ranks relative to the 90-year period of water years 1930-2019, unless otherwise noted. The illustrations are based on observed data (U.S. Geological Survey, 2020a) from the U.S. Geological Survey (USGS) National Streamgage Network (U.S. Geological Survey, 2020b). The period of water years 1930-2019 was evaluated because the number of streamgages in the network before 1930 was too small to provide statistically significant data to compute meaningful statistics in most regions of the country.

In the summary, reference is made to the term "runoff," which is defined as the amount of water flowing through a stream divided by the drainage basin area of the stream. The value of runoff quantifies the magnitude of water flowing through the Nation's rivers and streams in measurement units that can be compared from one area to another. In this summary, runoff for a specified period and geographic area is computed from all streamgages with complete streamflow records in the geographic area.

In all the graphics, a rank of 1 indicates the maximum annual flow of all years analyzed and a rank of 90 indicates the minimum annual flow of all years. Rankings of streamflow are grouped into much below normal, below normal, normal, above normal, and much above normal categories based on percentiles of flow (less than 10 percent, 10-24 percent, 25-75 percent, 76-90 percent, and greater than 90 percent, respectively; U.S. Geological Survey, 2020c). Streamflow conditions for States or water-resources regions are presented in the text in order of ranking from maximum to minimum flow; a maximum or minimum flow rank is not shown when there are ties in the rankings. Some of the data used to produce the maps and graphs are provisional and subject to change.

\section{National Overview}

Annual runoff in the Nation's rivers and streams during water year 2019 (13.62 inches) was much greater than the long-term (1930-2019) mean annual runoff of 9.37 inches for the contiguous United States (fig. 1). Nationwide, the 2019 streamflow ranked the highest out of the 90 years.

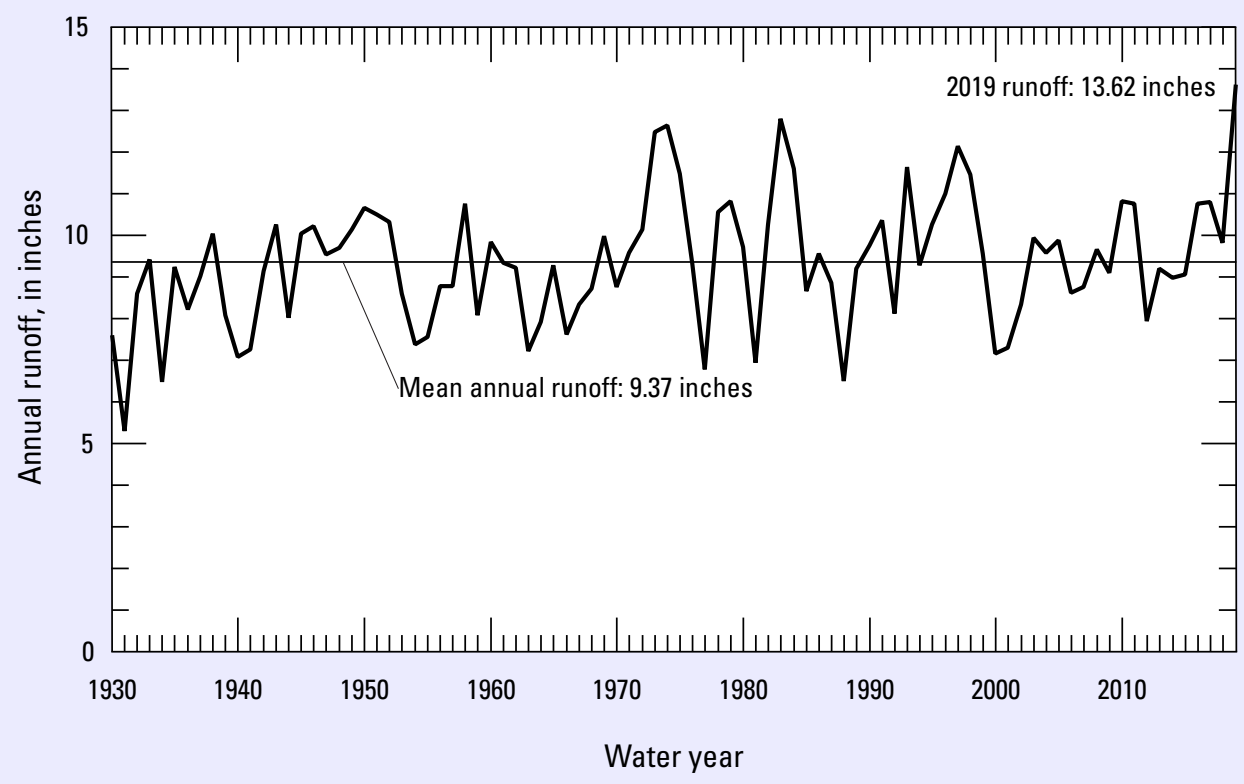

Figure 1. Annual runoff in the contiguous United States, water years 1930-2019. 
Streamflow was much below normal only in Washington (fig. 2). Streamflow was below normal in Alaska, Hawaii, and Oregon. Streamflow was above normal in Alabama, California, Georgia, Maine, Mississippi, Nevada, and Utah. Streamflow was much above normal in Arkansas, Connecticut, Delaware, District of Columbia, Iowa, Kentucky, Louisiana, Massachusetts, Missouri, New Hampshire, New York, North Carolina, North Dakota, Pennsylvania, Tennessee, Texas, Vermont, Virginia, and West Virginia. Record maximum streamflow was measured in Illinois, Indiana, Kansas, Maryland, Michigan, Minnesota, Nebraska, New Jersey, Ohio, Oklahoma, Rhode Island, South Dakota, and Wisconsin.

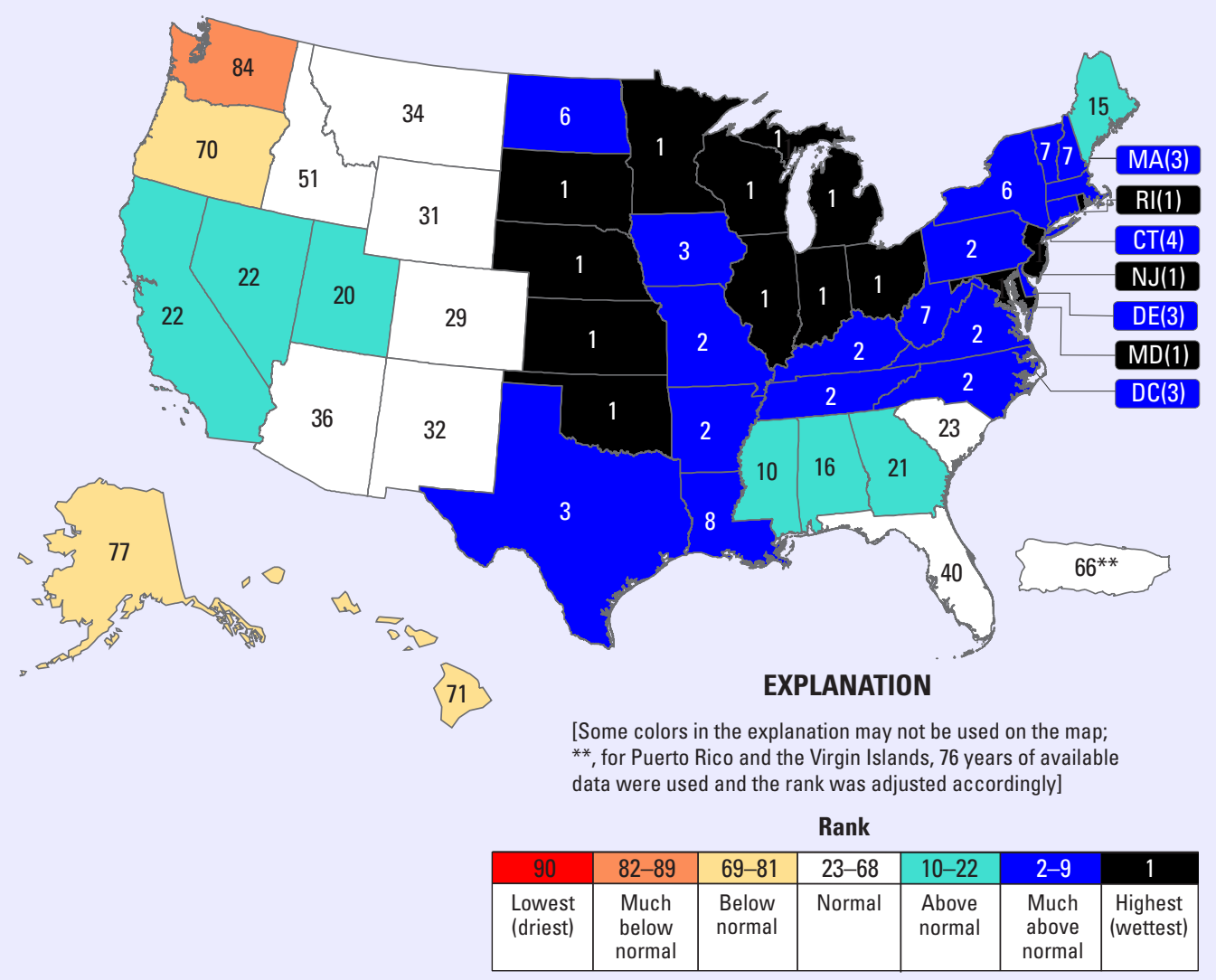

Figure 2. Statewide streamflow ranks of the United States for water year 2019 compared to water year 1930-2019 mean annual streamflow.

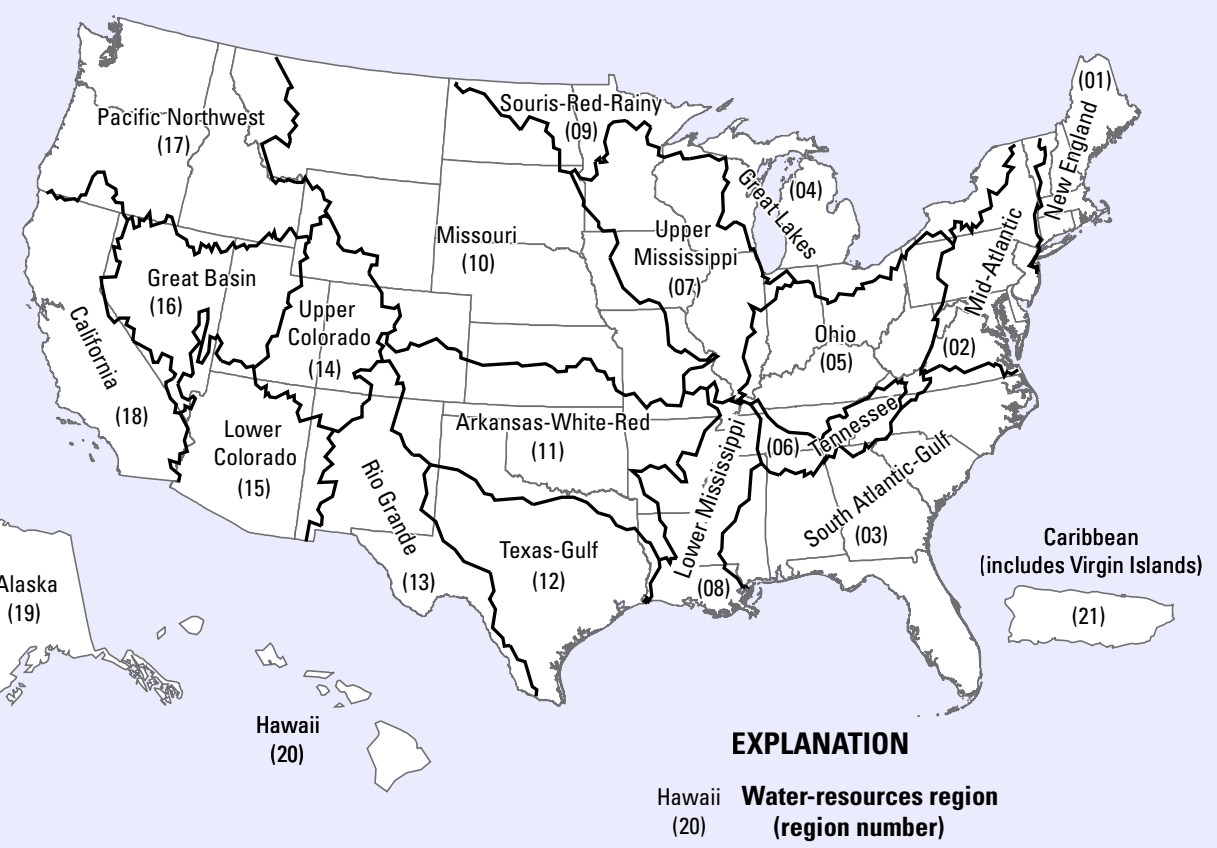

Figure 3. Water-resources regions. 
Streamflow was ranked at below normal levels in the Alaska, Hawaii, and Pacific Northwest regions (fig. 4). Streamflow was ranked above normal in the California, Great Basin, Rio Grande, Souris-Red-Rainy, and South Atlantic-Gulf regions. Much above normal streamflow was ranked in the Lower Mississippi, New England, Tennessee, and Texas-Gulf regions. Record maximum streamflow was measured in the Arkansas-White-Red, Great Lakes, Mid-Atlantic, Missouri, Ohio, and Upper Mississippi regions.

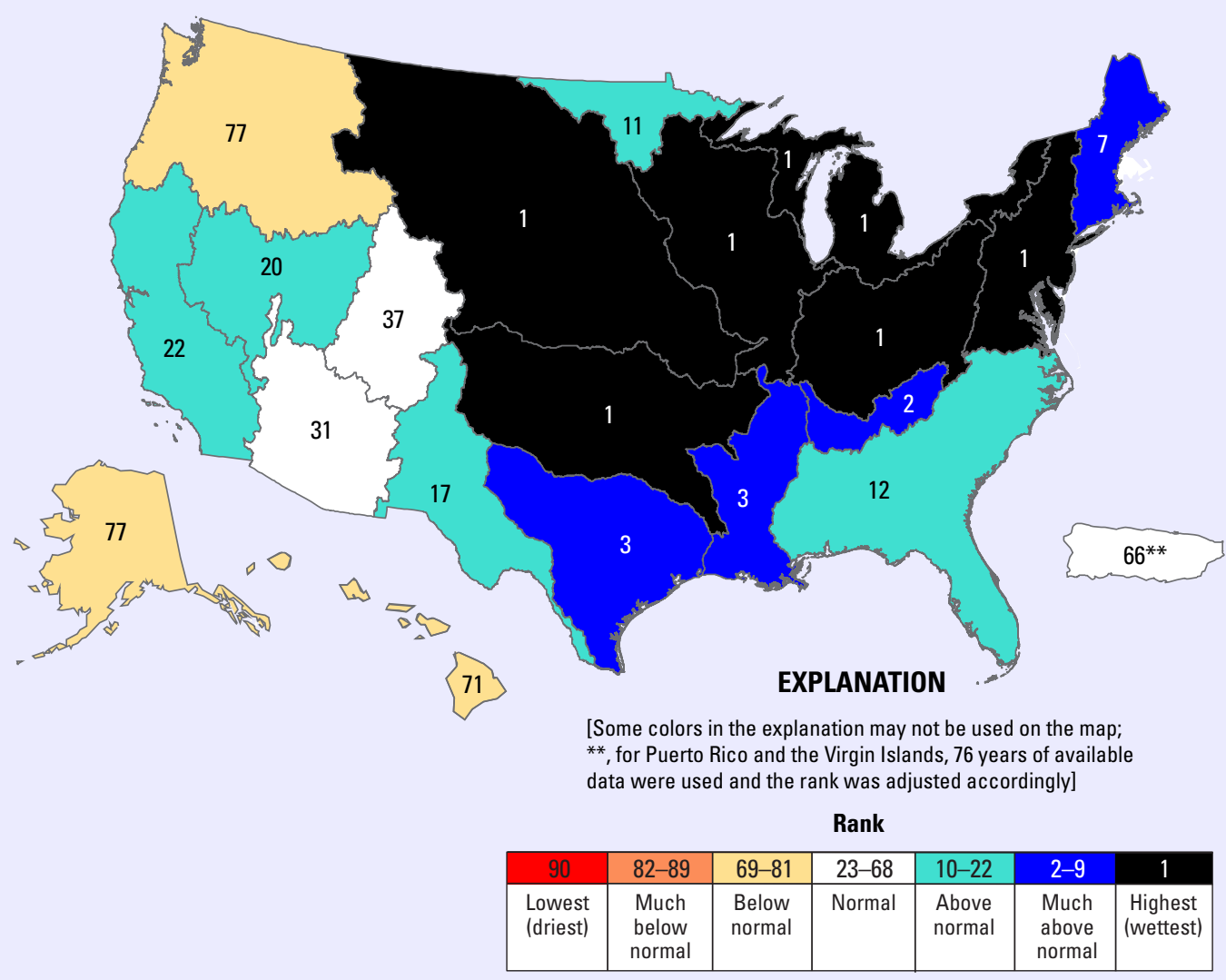

Figure 4. Regional streamflow ranks in the United States for water year 2019 compared to water year 1930-2019 mean annual streamflow.

\section{Seasonal Characteristics}

Autumn (October-December 2018) streamflow was ranked much below normal in Colorado (fig. 5). Streamflow was ranked below normal in California, Oregon, and Utah. Above normal streamflow was ranked in Arkansas, Florida, Illinois, Mississippi, and Oklahoma. Much above normal streamflow was ranked in Alabama, Connecticut,

Delaware, Georgia, Indiana, Kansas, Kentucky, Massachusetts, Michigan, Minne-sota, Nebraska, New

Hampshire, New York, Ohio, South Carolina, South Dakota, Tennessee, Vermont, and West Virginia. Record maximum streamflow was measured in District of Columbia, Iowa, Louisiana, Maryland, New Jersey, North Carolina, Pennsylvania, Rhode Island, Texas, Virginia, and Wisconsin. Nationwide, autumn-season streamflow ranked the highest out of 90 years.

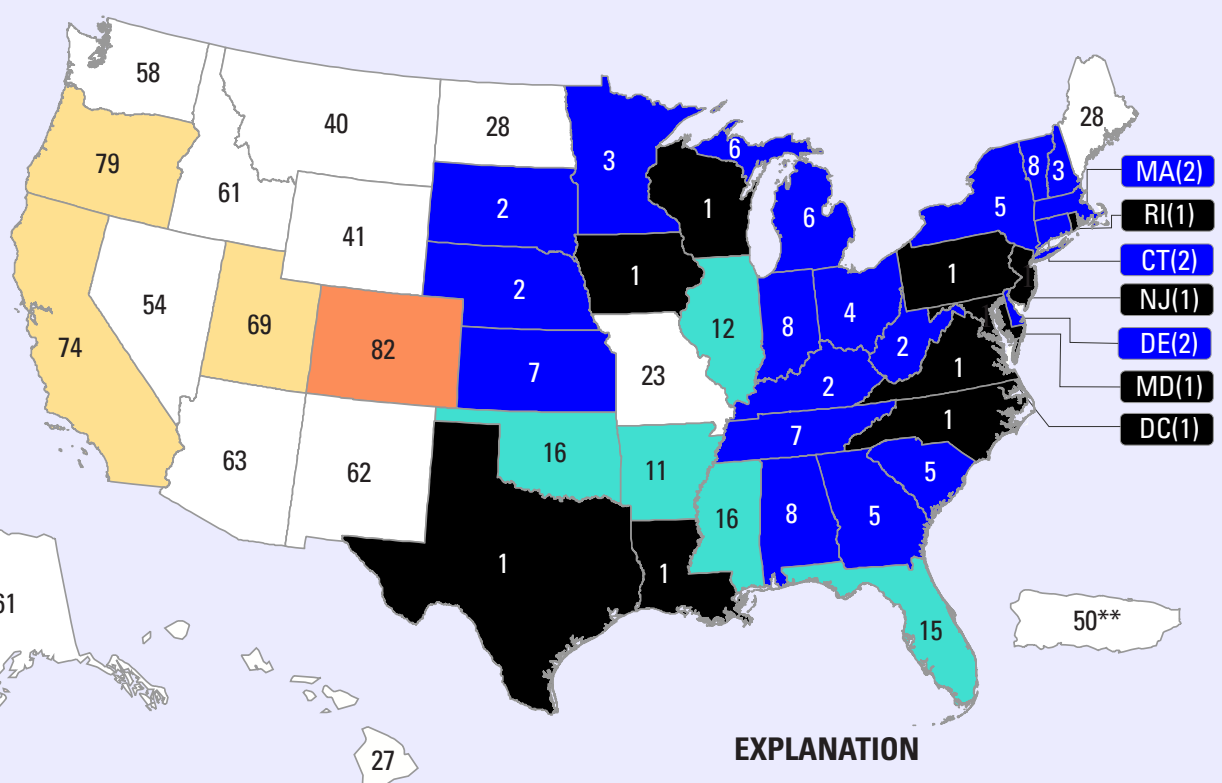

[Some colors in the explanation may not be used on the map; ${ }^{*}$, for Puerto Rico and the Virgin Islands, 76 years of available data were used and the rank was adjusted accordingly]

\begin{tabular}{|c|c|c|c|c|c|c|}
\multicolumn{1}{|c|}{ Rank } \\
\hline 90 & $82-89$ & $69-81$ & $23-68$ & $10-22$ & $2-9$ & 1 \\
\hline $\begin{array}{c}\text { Lowest } \\
\text { (driest) }\end{array}$ & $\begin{array}{c}\text { Much } \\
\text { below } \\
\text { normal }\end{array}$ & $\begin{array}{c}\text { Below } \\
\text { normal }\end{array}$ & Normal & $\begin{array}{c}\text { Above } \\
\text { normal }\end{array}$ & $\begin{array}{c}\text { Much } \\
\text { above } \\
\text { normal }\end{array}$ & $\begin{array}{c}\text { Highest } \\
\text { (wettest) }\end{array}$ \\
\hline
\end{tabular}

Figure 5. Autumn (October-December 2018) statewide ranks in the United States compared to water year 1930-2019 mean annual streamflow. 
Winter (January-March 2019) streamflow was ranked much below normal in Washington (fig. 6). Streamflow was ranked below normal in Idaho, Oregon, and Puerto Rico and the Virgin Islands. Above normal streamflow was ranked in Alabama, Arizona, California, Connecticut, Delaware, Georgia, Massachusetts, Mississippi, North Carolina, North Dakota, Oklahoma, Pennsylvania, Rhode Island, South Carolina, Texas, and West Virginia. Streamflow was ranked much above normal in Arkansas, District of Columbia, Illinois, Indiana, Kansas, Kentucky, Louisiana, Maryland, Missouri, New Jersey, Ohio, Tennessee, Virginia, and Wisconsin. Record maximum streamflow was measured in Iowa, Minnesota, Nebraska, and South Dakota. Nationwide, winter-season streamflow ranked second highest out of 90 years.

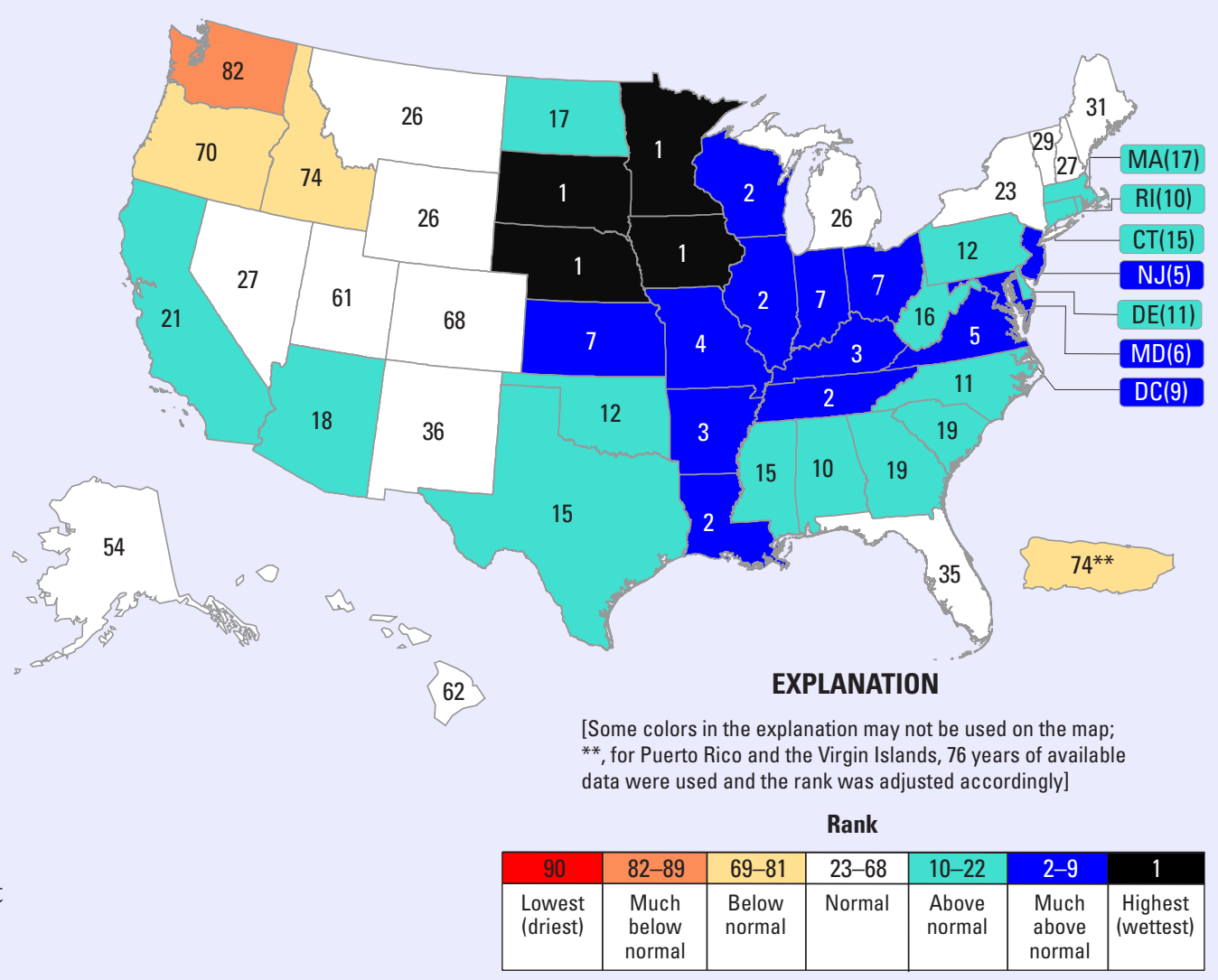

Figure 6. Winter (January-March 2019) statewide ranks in the United States compared to water

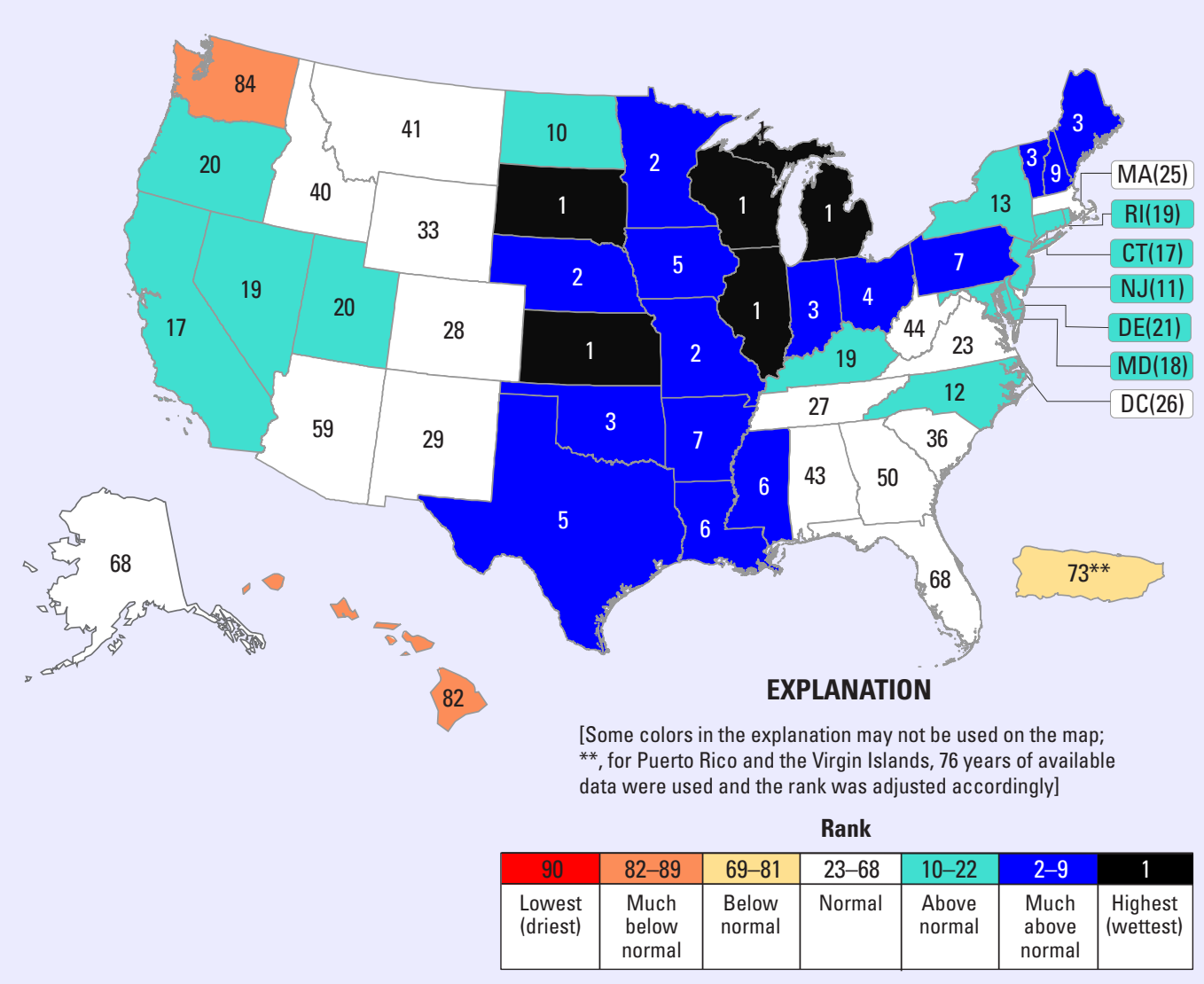

Figure 7. Spring (April-June 2019) statewide ranks in the United States compared to water

year 1930-2019 mean annual streamflow.

\section{year 1930-2019 mean annual streamflow.}

Spring (April-June 2019) streamflow was ranked much below normal in Hawaii and Washington (fig. 7). Below normal streamflow was ranked in Puerto Rico and the Virgin Islands. Above normal streamflow was ranked in California, Connecticut, Delaware, Kentucky, Maryland, Nevada, New Jersey, New York, North Carolina, North Dakota, Oregon, Rhode Island, and Utah. Streamflow was ranked much above normal in Arkansas, Indiana, Iowa, Louisiana, Maine, Minnesota, Mississippi, Missouri, Nebraska, New Hampshire, Ohio, Oklahoma, Pennsylvania, Texas, and Vermont. Record maximum streamflow was measured in Illinois, Kansas, Michigan, South Dakota, and Wisconsin. Nationwide, springseason streamflow ranked second highest out of 90 years. 
Summer (July-September 2019) streamflow was ranked much below normal in Alaska, Arizona, and Washington (fig. 8). Below normal streamflow was ranked in Alabama, Georgia, Hawaii, and South Carolina. Above normal streamflow was ranked in California, Iowa, Louisiana, Michigan, Mississippi, Nevada, Ohio, and Utah. Much above normal streamflow was ranked in Arkansas, Colorado, Illinois, Kansas, Minnesota, Missouri, Nebraska, North Dakota, Oklahoma, and Wisconsin. Record maximum streamflow was measured in South Dakota. Nationwide, summer-season streamflow ranked 14th highest out of 90 years.

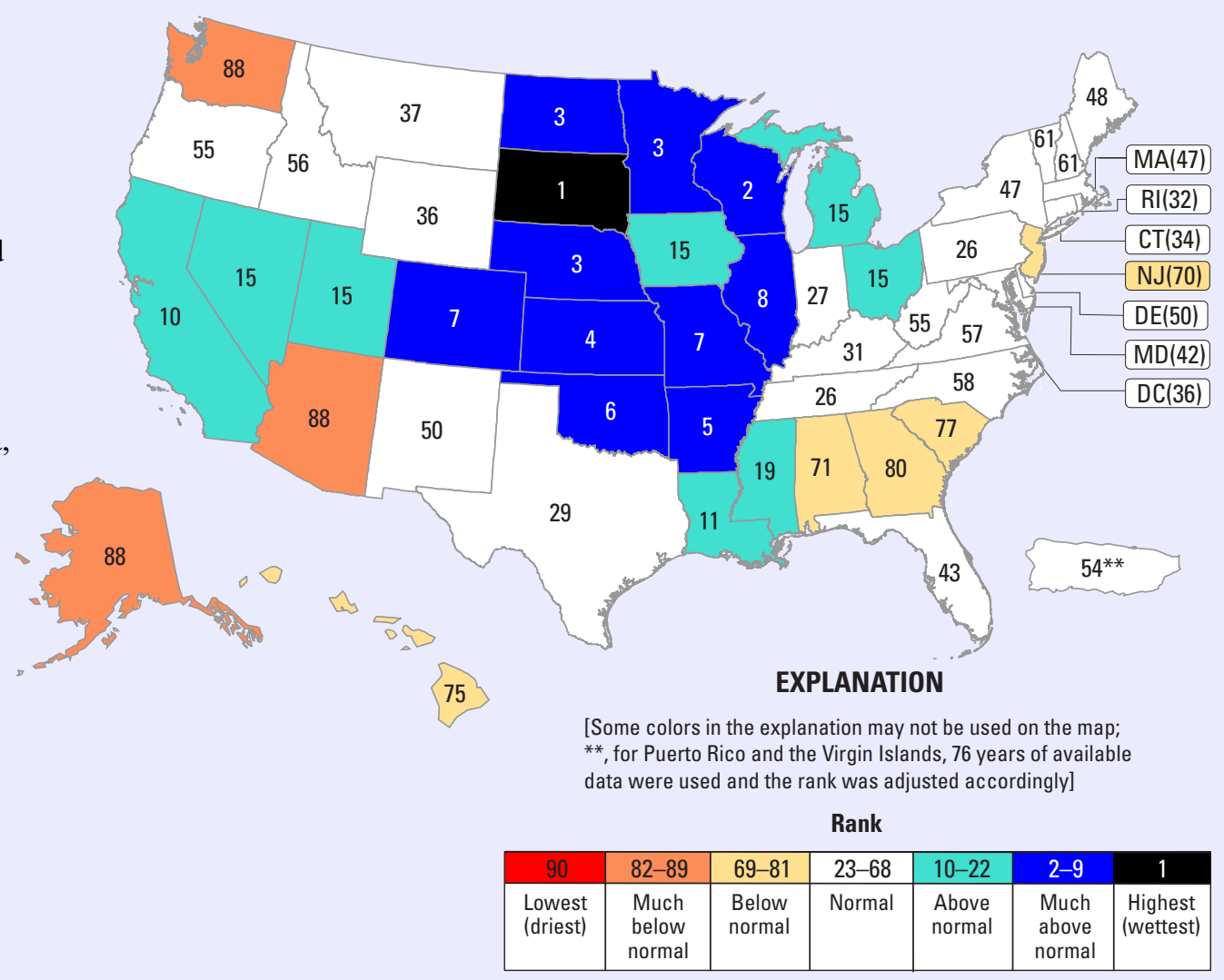

Figure 8. Summer (July-September 2019) statewide ranks in the United States compared to water year 1930-2019 mean annual streamflow.

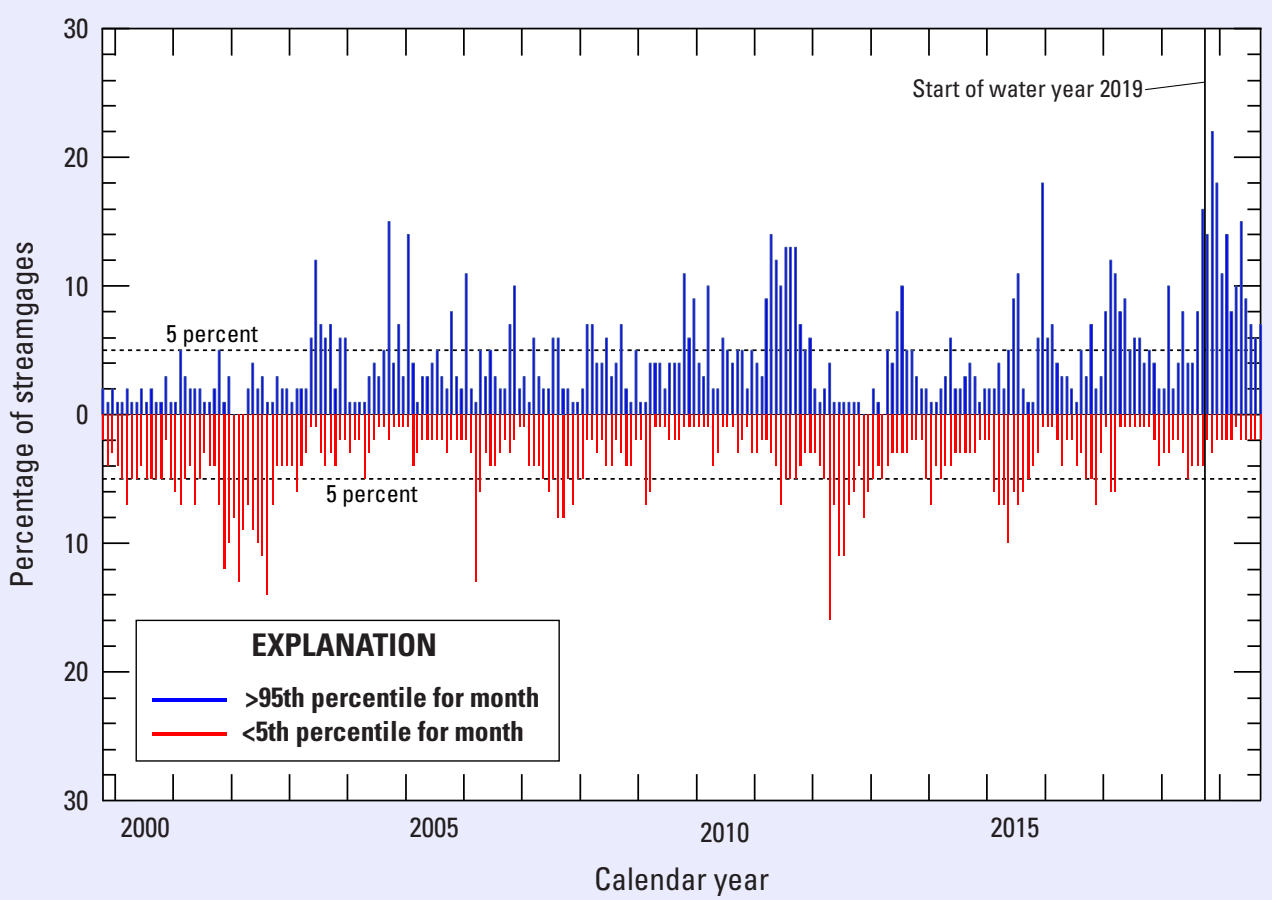

Figure 9. Percentage of streamgages with high and low monthly streamflow, October 1999September 2019. 


\section{Additional Information}

The USGS operated a nationwide network of more than 8,400 year-round, real-time streamflow gages in water year 2019. The real-time data from these stations are available at https://waterwatch.usgs.gov. Tables of data that summarize historical streamflow conditions by State, expressed as runoff, beginning in water year 1901, can be accessed at https://waterwatch.usgs.gov/?id=statesum. These tables are updated every few months to reflect the most current streamflow data.

The streamflow information used to prepare this summary also is used for water management, flood and drought monitoring, bridge design, and several recreational activities. To obtain real-time and archived streamflow data and information, visit the USGS National Water Information System at https://doi.org/10.5066/F7P55KJN (U.S. Geological Survey, 2020c). The National Streamflow Network, which is part of the Groundwater and Streamflow Information Program, is operated primarily by the USGS; however, funding to operate the network is provided by the USGS and about 1,400 Federal, State, Tribal, regional, and local partners. Additional streamflow information can be accessed at https://www.usgs.gov/water-resources/groundwaterand-streamflow-information/streamflow-monitoring?qtscience_support_page_related_con=0\#qt-science_support page_related_con.

\section{References}

U.S. Geological Survey, 2020a, USGS water data for the Nation: U.S. Geological Survey National Water Information System database, accessed June 2020 at https://doi.org/10.5066/ F7P55KJN.

U.S. Geological Survey, 2020b, Groundwater and Streamflow Information Program: U.S. Geological Survey web page, accessed June 2020 at https://www.usgs.gov/water-resources/ groundwater-and-streamflow-information.

U.S. Geological Survey, 2020c, Map of real-time streamflow compared to historical streamflow for the day of the year (United States): U.S. Geological Survey web page, accessed June 2020 at https://waterwatch.usgs.gov/?id=ww_current.

\section{—By Xiaodong Jian, David M. Wolock, Harry F. Lins, and} Steven J. Brady

For additional information, contact:

U.S. Geological Survey

415 National Center

Reston, VA 20192

https://www.usgs.gov/mission-areas/water-resources

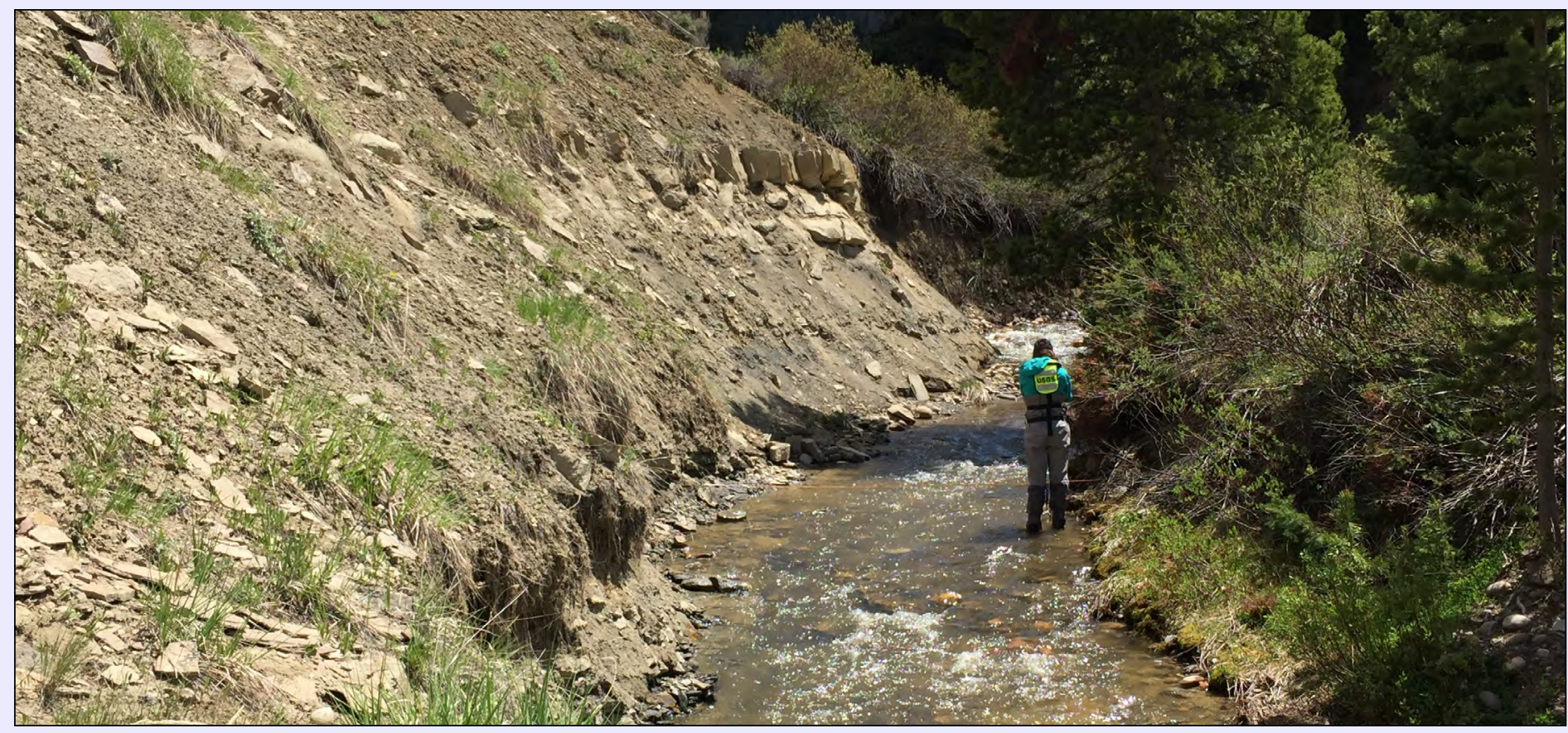

Streamflow measurement on Grouse Creek. Photograph taken June 18, 2019, in Moran, Wyoming, by Cheryl Miller, U.S. Geological Survey. 